Published by Al-Nahrain College of Medicine P-ISSN 1681-6579

E-ISSN 2224-4719

Email: iraqijms@colmed-alnahrain.edu.iq

http://www.colmed-alnahrain.edu.iq

http://www.iraqijms.net

Iraqi JMS 2018; Vol. 16(2)

\title{
Vaginal Progesterone Pessary for Preterm Labor Prevention in Women with a Short Cervix Early in The Second Trimester
}

\author{
Enas A.A. Khazaali FICMS (OG), CABOG
}

Dept. of Obstetrics and Gynecology, College of Medicine, Al-Nahrain University, Baghdad, Iraq

\section{Abstract \\ Background Objective}

Methods

Results

Conclusion

Keywords

Citation
The prevention of preterm birth is a major health care priority.

To evaluate the efficacy of vaginal progesterone pessary in reducing the rate of preterm delivery and subsequent neonatal morbidity and mortality events in pregnant women with a short cervical length early in the $2^{\text {nd }}$ trimester.

Women with a singleton pregnancy without a history of preterm labor nor a history of second trimester miscarriage, underwent cervical length measurement at 14+0 to $15+6$ weeks of gestation. Women found to have a cervical length less than $30 \mathrm{~mm}$ received vaginal progesterone pessary (400 $\mathrm{mg}$ per pessary) on daily basis, or no treatment. Primary outcome was preterm delivery rate before 37 weeks gestation. Secondary outcome includes neonatal morbidity and mortality events.

From the 7725 pregnant women screened between the period from April 2015 to January 2017, 613 were found to have a cervical length less than $30 \mathrm{~mm}$ and only 518 pregnant women met the inclusion criteria and agreed to participate in this study. However, only 492 were followed up till the time of delivery. From those 252 women administered $400 \mathrm{mg}$ vaginal progesterone pessary once daily at night and the remaining 240 women did not receive any form of progesterone and served as control. There was a significant reduction in preterm delivery rate less than 37 weeks gestation among women receiving progesterone vaginal pessary compared to the control group $11(4.4 \%)$ vs $38(15.8 \%)$, p value $<0.001$. Regarding neonatal outcome, there were significant reduction in the frequency of respiratory distress syndrome, low birth weight neonates and admissions to neonatal intensive care unit in women taking vaginal progesterone pessary compared to the control. While other neonatal morbidity and mortality events, incidence of neonatal congenital anomalies were not significantly different between the two groups.

Vaginal progesterone pessaries in women with a cervical length less than $30 \mathrm{~mm}$ early in the second trimester are found to be effective in reducing the rate of preterm birth and some of the prematurity related morbidity events. preterm labor, vaginal progesterone pessaries, short cervix, premature delivery

Khazaali EAA. Vaginal progesterone pessary for preterm labor prevention in women with a short cervix early in the second trimester. Iraqi JMS. 2018; 16(2): 133-143. doi: 10.22578/IJMS.16.2.4
List of abbreviations: $\mathrm{BMI}=$ Body mass index, $\mathrm{BPD}=$ Bronchopulmonary dysplasia, CNS = Central nervous system, 17-OHPC $=17$ hydroxy progesterone caproate, LMP = Last menstrual period, PTB = Preterm birth, RDS = Respiratory distress syndrome, TVU = Transvaginal ultrasound

\section{Introduction}

he definition of preterm birth (PTB) is delivery of a baby before 37 completed weeks of pregnancy ${ }^{(1)}$.
About one-quarter of PTB are iatrogenic usually for pre-eclampsia, fetal growth retardation or maternal disease. The remainder is due to spontaneous preterm labor and delivery ${ }^{(2)}$. There was steady improvement in the survival rates of preterm babies over the past two decades, mainly due to the introduction of surfactant therapy, wider spread use of antenatal steroids and improvement in neonatal respiratory management ${ }^{(2)}$. 
PTB is a leading cause of neonatal and infant mortality as well as short- and long-term disability. In developed countries, rates for PTB range between $6 \%$ and $12 \%$ and are generally higher in developing countries ${ }^{(3,4)}$.

Premature delivery in an under-resourced setting, place the baby at extremely high risk of death in the early neonatal period. The lower the gestational age at birth, the greater the need for more expensive interventions and support to improve the chances of infants' survival. In developing countries, the absence of skilled maternity care, leads to high rates of neonatal morbidity and mortality for premature babies. Despite increasing incidence of prematurity in both developed and developing countries, no significant advances have been made in the prevention or treatment of preterm delivery ${ }^{(3,4)}$.

It has been found that progesterone plays a major role in the maintenance of pregnancy and in the majority of mammals, labor is preceded by a decline in circulating progesterone levels ${ }^{(5)}$.

In the human, there is no systemic withdrawal of progesterone prior to labor, although there is an increase in the expressions of genes formerly repressed by progesterone ${ }^{(6)}$.

It has been widely thought that progesterone inhibits contractions principally by repressing contraction-associated proteins such as oxytocin, gap-junction proteins, prostaglandin receptors and prostaglandin-metabolizing enzymes ${ }^{(7,8)}$.

Preterm labor cannot be considered as a single disease entity, but it is a syndrome or symptom that may have one or more causes ${ }^{(3)}$.

Because of multifactorial (social, behavioral and biological) causes in preterm delivery, efforts in prevention measures have not been successful so far ${ }^{(9)}$.

Early identification of woman at risk and the use of prophylactic therapies are one of the most important strategies to reduce perinatal morbidity and mortality associated with PTB. Initial identification of women at high risk of preterm labor is based on their past obstetric history ${ }^{(10)}$.

A single previous preterm delivery increases the risk of preterm delivery in the next pregnancy by four folds compared with a previous delivery at term. However, the large majority of spontaneous preterm delivery occurs in nulliparous women, and progesterone has not been widely assessed in those women ${ }^{(11)}$.

Although women with of previous history PTB and those with multiple gestation are at the highest risk of preterm delivery ${ }^{(12,13)}$, the majority of spontaneous PTB occur in women with low risk (14).

There is good evidence that support the use of transvaginal sonographic measurement of cervical length to predict the risk of preterm labor in both low- and high-risk pregnancies and in symptomatic women (15).

Currently, there are two strategies in common use: a single measurement of cervical length usually at the time of the routine ultrasound scan at 18-22 weeks of gestation or a serial measurement of cervical length throughout the $2^{\text {nd }}$ and early $3^{\text {rd }}$ trimester of pregnancy. There is a direct relationship between cervical length and preterm delivery risk at any given gestational age, example, a cervical length of $15 \mathrm{~mm}$ or less at $20-24$ weeks predicts a $50 \%$ risk of preterm delivery prior to 34 weeks in a low risk population. However, identification of a risk of preterm labor as late as 23 weeks may be too late for any potential prophylactic therapies to be beneficial (16).

There is currently no effective method for the prediction of preterm labor in prime gravid women with no other significant risk factors for preterm delivery. However, it is possible to identify a subgroup of women who can be identified as being at risk of PTB depending on the use of screening tests e.g. measurement of cervical length, detection of fetal fibronectin in vaginal secretions and the presence of abnormalities of the genital tract. 
Commonly used therapies include cervical cerclage, non-steroidal anti-inflammatory drugs (NSAIDs) and progesterone ${ }^{(2)}$.

The weight of both clinical evidence and basic science currently points to progesterone being potentially beneficial in women at high risk of preterm delivery, except those with multiple gestation and there appear to be few if any side effects ${ }^{(2)}$.

The efficiency and safety of progestogens are related to individual pharmacologic properties of each drug within this class of medication and characteristics of the population that is treated (17).

Research among exposed women and controls showed no difference with respect to the occurrence of abnormalities of the central nervous system (CNS), limbs and joints, urogenital tract and circulatory tract between treated and untreated programs, even when 17 hydroxy progesterone caproate (17-OHPC) was administered in early pregnancy ${ }^{(18)}$.

Manuck et al. (19) demonstrated a variable response to 17-OHPC exposure, based on the progesterone receptor genotype.

The recommendation of the American College of Obstetrics and Gynecology about the use of antenatal progesterone to prevent preterm delivery is that: its use should be restricted to women incidentally found to have a short cervix (less than $15 \mathrm{~mm}$ ), or to women with a documented history of prior spontaneous preterm delivery at less than 37 weeks ${ }^{(20)}$.

It has been shown that the administration of progesterone decreases both the number of episodes of uterine contractions and the incidence of preterm birth in women at high risk for preterm delivery ${ }^{(21)}$.

The objective of this study was to evaluate the efficacy of vaginal progesterone pessary in reducing preterm delivery rate and subsequent neonatal morbidity and mortality events in pregnant women with a short cervical length early in the $2^{\text {nd }}$ trimester.

\section{Methods}

The present study was conducted from April 2015 to January 2017 in the ultrasound outpatient department at Al-Imamein AlKadhimein Medical City and in 5 ultrasound private clinics operated by an ultrasound specialist, and it was approved by the Institutional Review of the Iraqi Board of the participating center.

A verbal informed consent was taken from all the eligible participants before study entrance.

This trial enrolled 518 low risk asymptomatic women with a singleton pregnancy who were nulliparous or multiparous without a history of spontaneous PTB less than 37 weeks gestation nor 2nd trimester miscarriage and who were found to have a cervical length $<30 \mathrm{~mm}$ on transvaginal ultrasound scan at $14+0$ to $15+6$ weeks gestation.

Gestational age was estimated based on the last menstrual period (LMP), which was reported by the participants and was confirmed by ultrasound or ultrasound alone when LMP was unknown.

After emptying the urinary bladder, transvaginal measurement of cervical length was performed. The name of the ultrasound machine used is Voluson E6 ultrasound machine GE health care, the transvaginal probe used is IC5-9-D Micro Convex Endocavitary Probe. The cervical length was measured from the internal os to the external os along the endocervical canal.

All participating sonographers were experienced.

For each participant, baseline demographic data including maternal age, body mass index (BMI), level of education were collected. BMI was calculated around the time of the transvaginal scan, using the following formula: weight in kilograms $(\mathrm{Kg})$ divided by the height in meters squared $\left(\mathrm{Kg} / \mathrm{m}^{2}\right)$. Obstetric and medical history were taken and physical examination was done.

Exclusion criteria include women less than 18 years of age, women with a history of previous preterm delivery and $2^{\text {nd }}$ trimester miscarriage, vaginal bleeding, fetal congenital malformation or suspected chromosomal abnormalities (from the increased nuckal translucency thickness measurement above $2.9 \mathrm{~mm}$ ), cervical or abdominal cerclage in situ or planned cerclage, 
uterine anomalies e.g. bicornuate uterus or septate uterus, current or recent progesterone therapy within the previous 4 weeks, allergy to any ingredient of the pessaries, cervical dilatation, chronic maternal medical condition e.g. diabetes mellitus, chronic hypertension, liver disease, psychiatric disorders, epilepsy, porphyrias, known or suspected progesteronesensitive tumors e.g. breast cancer, deep venous thrombosis, pulmonary embolism, thrombophlebitis, heart attack or stroke.

All the participants were randomly allocated to receive either vaginal or rectal progesterone pessaries (trade name: cyclogest, company's name: Actavis, Barnstaple EX328NS, UK) 400 mg daily or no treatment till $36+6$ weeks gestation.

Progesterone pessaries were self-administered vaginally using the $400 \mathrm{mg}$ formulation, on daily basis at night. Those who had vaginal infection e.g. moniliasis and in those with recurrent cystitis the pessaries were applied rectally. However, in the presence of colitis or fecal incontinence, it was applied vaginally.

The treatment was initiated between $14+0$ and $15+6$ weeks of gestation and continued until $36+6$ weeks gestational age, rupture of membranes or delivery, whichever occurred first.

All the participants were followed-up every 3 weeks and were interviewed to determine the occurrence of any adverse events and to ensure about the compliance with the treatment in those who receive the progesterone pessaries.

Women who developed $2^{\text {nd }}$ trimester miscarriage (one) and those who were lost to be followed up (twenty-three) were excluded from the study as well as those who needed an emergency cerculage (two) which was done if cervical dilatation exceeds $1 \mathrm{~cm}$, in the presence of an intact membranes and in the absence of uterine contractions, significant vaginal bleeding and clinical or subclinical (increased c-reactive protein, increased white blood cell count) evidence of chorioamnionits. Progesterone pessaries were stored below 25 ${ }^{\circ} \mathrm{C}$ in a dry place.
Maternal outcome was preterm birth prior to 37 weeks gestation.

Neonatal outcome was recorded after delivery and up to the first 28 days of life and it included fetal death, neonatal death, or neonatal morbidity in the form of grade III or IV intraventricular hemorrhage, periventricular leukomalacia, respiratory distress syndrome (RDS), bronchopulmonary dysplasia (BPD), proven sepsis, necrotizing enterocolitis.

According to radiological appearance, intraventricular hemorrhage was classified as followed: (22)

Grade three intraventricular hemorrhage: the blood filling and distending the ventricular system. Dilated ventricles which are more than $50 \%$ full of blood

Grade four intraventricular hemorrhage: parenchymal involvement of hemorrhage, also known as periventricular venous infarction.

Periventricular leukomalacia is a form of whitematter brain injury, characterized by the necrosis (more often coagulation) of white matter near the lateral ventricles (23).

RDS was defined as need for artificial ventilation and an x-ray meeting RDS criteria (24).

BPD was defined as need for supplemental $\mathrm{O}_{2}$ during at first 28 days after birth ${ }^{(25)}$.

Analysis was by an intention to treat.

\section{Statistical analysis}

With using the Microsoft excel 2016 and GraphPad Prism version 6 software, most of data was categorical and presented as frequency and percentage, the comparison of these data between the two groups of study was done Using chi square test and Fisher exact test. Only age and body mass index were presented as mean \pm standard deviation and comparison done by an unpaired t-test. $P$ value less than 0.05 was considered significant.

\section{Results}

From the 7725 women scanned, 613 found to have a cervical length less than $30 \mathrm{~mm}$; and from the 613 women, 575 met the inclusion criteria. However, only, 518 pregnant women agreed to participate in this study. 
From the 518 women who participated in this study, 492 were followed-up till the time of delivery.

Of the remaining 26 women, 23 women were lost to follow-up and 3 were excluded from the study because one of them miscarried at $17+3$ weeks of gestation and two needed emergency cerclage for cervical dilatation one at $17+6$ weeks gestation and the other at $21+2$ weeks gestation.

From the 492 participants who were followed up; 252 women administered $400 \mathrm{mg}$ progesterone pessary once daily at night and the remaining 240 women did not receive any form of progestogens and served as control.
Thus, this study included two groups; pregnant women receiving vaginal or rectal progesterone pessaries, the study group $n=252$ and the control group $n=240$.

The two study groups were matched regarding maternal age $(26.34 \pm 3.62$ for women taking cyclogest and $26.44 \pm 3.63$ for control) $p$ value $=$ 0.759. Likewise, for the body mass index, no significant difference was found between the two groups $(28.49 \pm 2.34$ for women taking cyclogest and $28.6 \pm 2.28$ for control) $\mathrm{p}$ value $=$ 0.577 (table 1).

Table 1. Comparison of maternal age and body mass index between the two groups

\begin{tabular}{|c|c|c|c|}
\hline Parameter & $\begin{array}{l}\text { Women taking progesterone pessary } \\
\qquad \begin{array}{c}\mathrm{N}=252 \\
\text { Mean } \pm S D \\
\text { (Range) }\end{array}\end{array}$ & $\begin{array}{l}\text { Control } \\
\mathrm{N}=240 \\
\text { Mean } \pm \mathrm{SD} \\
\text { (Range) }\end{array}$ & P value* \\
\hline Age (yr) & $\begin{array}{l}26.34 \pm 3.62 \\
(19-34)\end{array}$ & $\begin{array}{c}26.44 \pm 3.63 \\
(19-35)\end{array}$ & 0.759 \\
\hline BMI $\left(\mathrm{kg} / \mathrm{m}^{2}\right)$ & $\begin{array}{c}28.49 \pm 2.34 \\
(24-32)\end{array}$ & $\begin{array}{c}28.6 \pm 2.28 \\
(25-32)\end{array}$ & 0.577 \\
\hline
\end{tabular}

* unpaired ttest

There was no significant difference between the two groups in other maternal related data including obstetric history, method of delivery, history of infertility \pm assisted reproductive technologies, cervical length and higher professional education as shown in table (2).

The frequency of preterm delivery was significantly less in women receiving cyclogest in comparison with control (11 vs 38 ), p value $<0.001$ as shown in table (3).

Table (4) shows a significant lower frequency of respiratory distress syndrome in neonates born to women taking progesterone pessary than those born to the controls; ( 9 vs 32), p value < 0.001 . With regard to the frequency of other neonatal morbidity and mortality events (apart from respiratory distress syndrome), no significant difference was shown between the two study groups (2 vs 7), $\mathrm{p}$ value $=0.099$, as illustrated in table (4) as well.

Table (5) demonstrated the presence of significant lower frequency of low birth weight neonates born from women taking progesterone pessary than those born to the controls ( 5 vs 26), $p$ value $<0.001$. Moreover, there was no significant difference regarding the frequency of congenital anomalies in the neonates between the two study groups (one case of ventricular septal defect in women taking progesterone pessary vs one case of cleft lip in control group), $p$ value $=1.000$, furthermore, a significant lower frequency of admission of neonates to neonatal intensive care unit (NICU) was shown between women taking progesterone pessary and control group (10 vs 34$)$, $p$ value $<0.001$. 
Table 2. Comparison of other maternal related data between the two groups

\begin{tabular}{|c|c|c|c|c|}
\hline \multicolumn{2}{|c|}{ Parameter } & $\begin{array}{c}\text { Women taking } \\
\text { progesterone pessary } \\
\mathrm{N}=252 \\
\text { No. (\%) }\end{array}$ & $\begin{array}{l}\text { Control } \\
N=240 \\
\text { No. }(\%)\end{array}$ & P value* \\
\hline \multirow{2}{*}{$\begin{array}{c}\text { Obstetric } \\
\text { history }\end{array}$} & Nulliparous & $95(37.7)$ & $93(38.7)$ & \multirow{2}{*}{0.853} \\
\hline & Multiparous & $157(62.3)$ & $147(61.3)$ & \\
\hline \multirow{2}{*}{$\begin{array}{c}\text { Method of } \\
\text { delivery }\end{array}$} & Vaginal & $215(85.3)$ & $207(86.3)$ & \multirow{2}{*}{0.797} \\
\hline & Cesarean section & $37(14.7)$ & $33(13.7)$ & \\
\hline \multirow{2}{*}{$\begin{array}{c}\text { History of } \\
\text { infertility } \pm \text { ART }\end{array}$} & Positive & $0(0.0)$ & $0(0.0)$ & \multirow{2}{*}{1.000} \\
\hline & Negative & $252(100)$ & $240(100)$ & \\
\hline \multirow{2}{*}{ Cervical length } & $<20 \mathrm{~mm}$ & $42(16.7)$ & $39(16.2)$ & \multirow{2}{*}{0.904} \\
\hline & $20-30 \mathrm{~mm}$ & $210(83.3)$ & $201(83.8)$ & \\
\hline \multirow{2}{*}{$\begin{array}{c}\text { Higher } \\
\text { professional } \\
\text { education } \\
\end{array}$} & Present & $97(38.5)$ & $90(37.5)$ & \multirow{2}{*}{0.853} \\
\hline & Absent & $155(61.5)$ & $150(62.5)$ & \\
\hline
\end{tabular}

* Fishers' exact test, ART: Assisted reproductive technologies

Table 3. Comparison of preterm delivery between 2 groups

\begin{tabular}{cccc}
\hline & Women taking progesterone pessary & Control & \\
Parameter & $\mathbf{N = 2 5 2}$ & $\mathbf{N}=\mathbf{2 4 0}$ & P value* \\
& No. (\%) & No. (\%) & \\
\hline Preterm delivery & $11(4.4)$ & $38(15.8)$ & \multirow{2}{*}{0.001} \\
Term delivery & $241(95.6)$ & $202(84.2)$ & \\
\hline
\end{tabular}

* Fishers' exact test

Table 4. Comparison of respiratory distress syndrome and other neonatal morbidity and mortality events between 2 groups

\begin{tabular}{|c|c|c|c|c|}
\hline \multicolumn{2}{|c|}{ Parameter } & $\begin{array}{c}\text { Women taking } \\
\text { progesterone pessary } \\
\mathrm{N}=252 \\
\text { No. }(\%)\end{array}$ & $\begin{array}{l}\text { Control } \\
\begin{array}{l}\mathrm{N}=240 \\
\text { No. (\%) }\end{array}\end{array}$ & $P$ value* \\
\hline \multirow{2}{*}{$\begin{array}{l}\text { Respiratory distress } \\
\text { syndrome }\end{array}$} & Present & $9(3.6)$ & $32(13.3)$ & \multirow{2}{*}{$<0.001$} \\
\hline & Absent & $243(96.4)$ & $208(86.7)$ & \\
\hline \multirow{2}{*}{$\begin{array}{l}\text { Other morbidity or } \\
\text { mortality events }\end{array}$} & Present & $2(0.8)$ & $7(2.9)$ & \multirow{2}{*}{0.099} \\
\hline & Absent & $250(99.2)$ & $233(97.1)$ & \\
\hline
\end{tabular}

* Fishers' exact test 
Iraqi JMS 2018; Vol. 16(2)

Table 5. Comparison of neonates' parameters between the two groups

\begin{tabular}{|c|c|c|c|c|}
\hline Paramet & & $\begin{array}{c}\text { Women taking } \\
\text { progesterone pessary } \\
\mathrm{N}=\mathbf{2 5 2} \\
\text { No. (\%) }\end{array}$ & $\begin{array}{l}\text { Control } \\
N=240 \\
\text { No. }(\%)\end{array}$ & P value* \\
\hline \multirow{2}{*}{$\begin{array}{c}\text { Low birth weight } \\
\text { neonates }\end{array}$} & Present & $5(2.0)$ & $26(10.8)$ & \multirow{2}{*}{$<0.001$} \\
\hline & Absent & $247(98.0)$ & $214(89.2)$ & \\
\hline \multirow{2}{*}{$\begin{array}{c}\text { Neonates with } \\
\text { congenital anomalies }\end{array}$} & Present & $1(0.4)$ & $1(0.4)$ & \multirow{2}{*}{1.000} \\
\hline & Absent & $251(99.6)$ & $239(99.6)$ & \\
\hline \multirow{2}{*}{ Admission to NICU } & Present & $10(4.0)$ & $34(14.2)$ & \multirow{2}{*}{$<0.001$} \\
\hline & Absent & $242(96.0)$ & $206(85.8)$ & \\
\hline
\end{tabular}

* Fishers' exact test, NICU: Neonatal intensive care unit

Concerning incidence of treatment related adverse events, no significant difference was found between women taking cyclogest and control groups (5 vs 0), $p$ value $=0.062$ as shown in table (6). Only five patients from the
252 experienced minor side effects in the form of soreness and flatulence with rectal administration and leakage of the pessary with rectal and vaginal administration.

Table 6. Comparison of incidence of treatment related adverse events between the two groups

\begin{tabular}{cccc}
\hline $\begin{array}{c}\text { Treatment adverse } \\
\text { events }\end{array}$ & $\begin{array}{c}\text { Women taking progesterone pessary } \\
\mathbf{N}=\mathbf{2 5 2} \\
\mathbf{N o . ~ ( \% ) ~}\end{array}$ & $\begin{array}{c}\text { Control } \\
\mathbf{N}=\mathbf{2 4 0} \\
\text { No. (\%) }\end{array}$ & \multirow{2}{*}{ P value* } \\
\hline Present & $5(1.98)$ & $0(0.0)$ & 0.062 \\
Absent & $247(98.02)$ & $240(100)$ & \multirow{2}{*}{} \\
\hline
\end{tabular}

\footnotetext{
* Fishers' exact test
}

\section{Discussion}

The prevention of preterm birth is a major health care priority ${ }^{(26)}$.

The only class of medication to demonstrate significant reductions repeatedly in the rate of early preterm birth are progestogens, natural progesterone or the synthetic 17-hydroxy progesterone caproate (17-OHPC) ${ }^{(27,28)}$.

The rationale behind the use of progesterone supplementations in reducing the rate of preterm birth is the following fact: although there is no significant change in progesterone concentration in the maternal circulation in the weeks preceding labor, the onset of labor both at term and preterm is associated with a functional withdrawal of progesterone activity $(8,29,30)$.

The vaginal route of drug delivery results in a greater concentration of supplemental progesterone within the uterus and cervix compared to serum (a first uterine pass effect) (31).

In 2003, Da Fonseca et al. ${ }^{(32)}$ reported a lower rate of preterm delivery in women at high risk and who receive a $100 \mathrm{mg}$ vaginal suppository daily, $13.8 \%$ before 37 weeks compared with the placebo group $28 \%$ before 37 weeks.

In a similar study, Meis et al. ${ }^{(33)}$ used weekly injections of $250 \mathrm{mg}$ of $17 \alpha$-hydroxy progesterone caproate between 16 and 36 and this reduced the preterm delivery rate from 55 to $36 \%$ before 37 weeks. In this study, the neonates of mothers treated with progesterone had lower morbidity.

In the current study, there was further reduction in the rate of preterm delivery in the progesterone treated group than in the control group ( $4.4 \%$ versus $15.8 \%)$ as well as the findings of our study were translated into a significant reduction in RDS, low birth weight 
infants and overall neonatal morbidity and mortality events in women who were taken cyclogest vaginal pessary compared to control group.

In agreement with the findings of the current study, a randomized clinical trial of vaginal progesterone capsules to prevent preterm delivery in women with a short cervix (defined as $15 \mathrm{~mm}$ or less) on transvaginal ultrasound at 20-25 weeks' gestation, reported a 44\% reduction in the rate of preterm delivery $(19.2 \% \text { vs } 34.4 \%)^{(34)}$. However, in this study, the reduction in the rate of preterm delivery was $72 \%$. This probably can be explained by earlier gestational age of intervention, which was at 15 weeks gestation as well by the longer cervical length of the women enrolled in our study (less than $30 \mathrm{~mm}$ ). In addition to the above findings our trial was associated with a significant improvement in neonatal outcome, which was not the case in the study done at $2007^{\text {(34). }}$

The above difference in the findings might be explained by the following fact: the risk of preterm birth based on cervical length varies according to the population in which the measurement is obtained and the gestational age in which a short cervix is identified ${ }^{(14,35)}$.

In line with finding of the current study, a large trial done at $2009^{(36)}$ measured cervical length at enrollment and at 28 weeks gestation in asymptomatic singletons, there was significantly smaller difference in the measurement of cervical length at these time points and significantly longer cervices at 28 weeks gestation in women who were treated with progesterone.

It has been found that natural progesterone exposure, significantly decrease contraction frequency ${ }^{(32,37) \text {. }}$

Another trial that showed findings similar to those found in the current study is that done by Maher et al., who demonstrated a significant reduction in preterm birth at $<34$ weeks with supplemental vaginal progesterone $(16.6 \% \text { vs } 25.7 \%)^{(38)}$, although the reduction in this study is more marked.

Hassan et al. (39) and Romero et al. (40) demonstrated that progesterone treatment indicated for a sonographic short cervix based on a universal screening strategy by TVU scanning can reduce the rate of preterm birth.

In the current study, we extended the upper limit of cervical length to less than $30 \mathrm{~mm}$ to explore whether vaginal progesterone pessaries would have a beneficial effect above the limit of cervical lengths included in the previous trials and therefore expand its therapeutic range.

As well our treatment protocol began at earlier gestation (15 weeks) than in the previous studies and continued till the time of delivery or up to 36 weeks +6 days because it is possible that earlier treatment may confer more beneficial effects and this what has been shown in our results in comparison with the findings of the previous trials.

However, the findings of this study disagree with that shown by Grobman et al. (41) who conducted a randomized trial among nulliparous women with a singleton gestation and mid trimester cervical length $<30 \mathrm{~mm}$, weekly injections with $17 \quad \alpha$-hydroxy progesterone caproate or placebo did not alter the frequency of preterm birth less than 37 weeks of gestation or neonatal outcome. Other investigators observed that vaginal progesterone but not 17 a-hydroxy progesterone caproate was associated with beneficial effects ${ }^{(42)}$.

The reason for this discrepancy in the findings between this trial and other trials including ours, may be related to the type, dose and route of administration of progesterone.

With regard to the risk of congenital anomaly in the progesterone treated group, our findings did not show any increase.

There is one concern exist is a possible increased risk of hypospadias in male offspring exposed to exogenous progestins ${ }^{(43)}$ even if this risk is real, it is limited to exposure prior to 11 weeks gestation.

In the current study, there was no report of significant side effects in the progesterone treated group. However, long-term side effects on mothers and infants should be considered in further investigation.

Adverse effects of progesterone suppositories were not mentioned $(32,34,44)$. 
The main implication of this study for clinical practice is that universal screening of women with transvaginal ultrasound to measure cervical length early in the second trimester to identify women at risk of preterm labor can now be coupled with an intervention, the administration of vaginal progesterone to reduce the rate of preterm labor and improve neonatal outcome.

The limitation of this trial is that it is not double blind and not placebo controlled.

This study concluded that vaginal progesterone pessaries in women with a cervical length less than $30 \mathrm{~mm}$ early in the second trimester is effective in reducing the rate of preterm birth and some of the prematurity related morbidity and mortality events.

\section{Acknowledgments}

The author would like to thank all patients who did agree to participate in this study as well as special thanks to the ultrasound specialist who had a vital role in the current work.

\section{Conflict of interest}

The author declares no conflict of interest.

\section{Funding}

Self-funding.

\section{References}

1. Murphy DJ. Epidemiology and environmental factors in preterm labour. Best Pract Res Clin Obstet Gynaecol. 2007; 21: 773-89. doi: 10.1016/j.bpobgyn.2007.03.001.

2. Bennett P. Preterm Labor. In: Edmonds DK (ed). Dewhursts Textbook of obstetrics \& gynecology. $8^{\text {th }}$ ed. Wiley Online Library; 2012. p. 338-55. doi: 10.1002/9781119979449.

3. Goldenberg RL, Culhane JF, lams JD, et al. Epidemiology and causes of preterm birth. Lancet. 2008; 371(9606): 75-84. doi: 10.1016/S01406736(08)60074-4.

4. Lang C, lams J. Goals and strategies for prevention of preterm birth: an obstetric perspective. Pediatr Clin North Am. 2009; 56(3): 537-63. doi: 10.1016/j.pcl.2009.03.006.

5. Zakar T, Mesiano S. How does progesterone relax the uterus in pregnancy? N Engl J Med. 2011; 364(10): 972-3. doi: 10.1056/NEJMcibr1100071.

6. Mesiano S, Welsh TN. Steroid hormone control of myometrial contractility and parturition. Semin Cell Dev Biol. 2007; 18(3): 321-31. doi: 10.1016/j.semcdb.2007.05.003.
7. Challis JRG, Matthews SG, Gibb W, et al. Endocrine and paracrine regulation of birth at term and preterm. Endocr Rev. 2000; 21: 514-50. doi: 10.1210/edrv.21.5.0407.

8. Norwitz ER, Lye SJ. Biology of parturition. In: Creasy RK, Resnick R, lams JD, et al, (eds). Creasy \& Resnick's Maternal-Fetal Medicine. $6^{\text {th }}$ ed. Philadelphia: Elsevier; 2009. p. 69-85.

9. American College of Obstetricians and Gynecologists ACOG Practice Bulletin. Assessment of risk factors for preterm birth. Clinical management guidelines for obstetrician-gynecologists. Number 31, October 2001. (Replaces Technical Bulletin number 206, June 1995; Committee Opinion number 172, May 1996; Committee Opinion number 187, September 1997; Committee Opinion number 198, February 1998; and Committee Opinion number 251, January 2001). Obstet Gynecol. 2001; 98(4): 709-16.

10. Flood K, Malone FD. Prevention of preterm birth. Seminars Fetal Neonat Med. 2012; 17: 58e-e63.

11. lams JD, Goldenberg RL, Mercer BM, et al. The Preterm prediction study: can low risk women destined for spontaneous preterm birth be identified? Am J Obstet Gynaecol. 2001, 184(4): 6525. doi: 10.1067/mob.2001.111248.

12. Ananth CV, Getahun D, Peltier MR, et al. Recurrence of spontaneous versus medically indicated preterm birth. Am J Obstet Gynecol. 2006; 195(3): 643-50. doi: 10.1016/j.ajog.2006.05.022.

13. Kazemier B, Buijs PE, Mignini L, et al. Impact of obstetric history on the risk of spontaneous preterm birth in singleton and multiple pregnancies: a systematic review. BJOG. 2014; 121(10): 1197-208; discussion 1209. doi: 10.1111/1471-0528.12896.

14. lams JD, Goldenberg RL, Meis PJ, et al. The length of the cervix and the risk of spontaneous premature delivery. National Institute of Child Health and Human Development Maternal Fetal Medicine Unit Network. N Engl J Med. 1996; 334(9): 567-72. doi: 10.1056/NEJM199602293340904.

15. Greco E, Lange A, Ushakov F, et al. Prediction of spontaneous preterm delivery from endocervical length at 11 to 13 weeks. Prenatal Diagnosis. 2011;31(1): 84-9. doi: 10.1002/pd.2640.

16. Sinno A, Usta IM, Nassar AH. A short cervical length in pregnancy: management options. Am J Perinatol. 2009; 26(10): 761-70. doi: 10.1055/s-0029-1239495.

17. O'Brien JM, Lewis DF. Prevention of preterm birth with vaginal progesterone or 17-alphahydroxyprogesterone caproate: a critical examination of efficacy and safety Am J Obstet Gynecol. 2016; 214(1): 45-56. doi: 10.1016/j.ajog.2015.10.934.

18. Dudas I, Gidai J, Czeizel AE. Population-based case control teratogenic study of hydroxyprogesterone treatment during pregnancy. Congenit Anom (Kyoto). 2006; 46(4): 194-8. doi: 10.1111/j.17414520.2006.00128.x.

19. Manuck TA, Lai $Y$, Meis PJ, et al. Progesterone receptor polymorphisms and clinical response to 17 alpha-hydroxyprogesterone caproate. Am J Obstet 
Gynecol. 2011; 205(2): 135.e1-9. doi: 10.1016/j.ajog.2011.03.048.

20. Society for Maternal Fetal Medicine Publications Committee. ACOG Committee Opinion number 419 October 2008 (replaces no. 291, November 2003). Use of progesterone to reduce preterm birth. Obstet Gynecol. 2008; 112(4): 963-5. doi: 10.1097/AOG.0b013e31818b1ff6.

21. Tita AT, Rouse DJ. Progesterone for preterm birth prevention: an evolving intervention. Am J Obstet Gynaecol. 2009; 200(3): 219-24. doi: 10.1016/j.ajog.2008.12.035.

22. McCrea HJ, Ment LR. The diagnosis, management, and postnatal prevention of intraventricular hemorrhage in the preterm neonate. Clin Perinatol. 2008; 35(4): 777-92, vii. doi: 10.1016/j.clp.2008.07.014.

23. Back SA, Riddle A, McClure MM. Maturationdependent vulnerability of perinatal white matter in premature birth. Stroke. 2007; 38(2 suppl): 724-30. doi: 10.1161/01.STR.0000254729.27386.05.

24. Ferguson ND, Fan E, Camporota L, et al. The Berlin definition of ARDS: an expanded rationale, justification, and supplementary material. Intensive Care Med. 2012; 38(10): 1573-82. doi: 10.1007/s00134-012-2682-1.

25. Jobe AH, Bancalari E. Bronchopulmonary dysplasia. Am J Respir Crit Care Med. 2001, 163(7), 1723-9. doi: 10.1164/ajrccm.163.7.2011060.

26. Food and Drug Administration. 17a-Alpha Hydroxyprogesterone Caproate for Prevention of Preterm Birth. Overview of FDA Background Document. [cited; Available from: https://www.fda.gov/ohrms/dockets/ac/06/briefing/ 2006-4227B1-02-01-FDA-Background.pdf. [Accessed 25 March 2011].

27. Romero R, Yeo L, Miranda J, et al. A blueprint for the prevention of preterm birth: vaginal progesterone in women with a short cervix. J Perinat Med. 2013; 41(1): 27-44. doi: 10.1515/jpm-2012-0272.

28. Lewis DF, Baker SL, Stauffer R. Short cervix and vaginal progesterone: a model on how to tackle the problem of idiopathic preterm labor. J Reprod Med. 2013; 58(9-10): 434-7.

29. Renthal NE, Chen CC, Williams KC, et al. miR-200 family and targets, ZEB1 and ZEB2, modulate uterine quiescence and contractility during pregnancy and labor. Proc Natl Acad Sci U S A. 2010; 107(48): 2082833. doi: 10.1073/pnas.1008301107.

30. Mesiano S, Wang $X$, Norwitz ER. Progesterone receptors in the human pregnancy uterus: do they hold the key to birth timing? Reprod Sci. 2011; 18(1): 6-19. doi: 10.1177/1933719110382922.

31. Cicinelli E, De Ziegler D, Bulletti C, et al. Direct transport of progesterone from vagina to uterus. Obstet Gynecol. 2000; 95(3): 403-6.

32. Da Fonseca EB, Bittar RE, Carvalho $\mathrm{MH}$, et al. Prophylactic administration of progesterone by vaginal suppository to reduce the incidence of spontaneous preterm birth in women at increased risk: a randomized placebo-controlled double-blind study. Am J Obstet Gynecol. 2003; 188(2): 419-24.

33. Meis PJ, Klebanoff $M$, Thom $E$, et al. Prevention of recurrent preterm delivery by 17 alphahydroxyprogesterone caproate. N Engl J Med. 2003; 348(24): 2379-85. doi: 10.1056/NEJMoa035140.

34. Fonseca EB, Celik E, Parra M, et al. Progesterone and the risk of preterm birth among women with a short cervix. N Engl J Med. 2007; 357 (5): 462-9. doi: 10.1056/NEJMoa067815.

35. Berghella V, Roman A, Daskalakis C, Ness A, Baxter JK. Gestational age at cervical length measurement and the incidence of preterm birth. Obstet Gynecol. 2007; 110(2 Pt 1): 311-7. doi: 10.1097/01.AOG.0000270112.05025.1d.

36. O'Brien JM, De Franco EA, Adair CD, et al. Effect of progesterone on cervical shortening in women at risk for preterm birth: secondary analysis from a randomized, double-blind, placebo- controlled trial. Ultrasound Obstet Gynecol. 2009; 34(6): 653-9. doi: 10.1002/uog.7338.

37. O'Brien JM, Ho SJ, Istwan $\mathrm{N}$, et al. Uterine activity in women receiving 17alphahydroxyprogesteronecaproate for preterm birth prevention: an observational study. Am J Perinatol. 2010; 27(2): 157-62. doi: 10.1055/s-0029-1234033.

38. Maher MA, Abdelaziz A, Ellaithy $M$, et al. Prevention of preterm birth: a randomized trial of vaginal compared to intramuscular progesterone. Acta Obstet Gynecol Scand. 2013; 92(2): 215-22. doi: 10.1111/aogs.12017.

39. Hassan SS, Romero R, Vidyadhari D, et al. Vaginal progesterone reduces the rate of preterm birth in women with a sonographically short cervix: a multicenter, randomized, double-blind, placebocontrolled trial. Ultrasound Obstet Gynecol. 2011; 38(1): 18-31. doi: 10.1002/uog.9017.

40. Romero R, Nicolaides KH, Conde-Agudelo A, et al. Vaginal progesterone in women with an asymptomatic sonographic short cervix in the midtrimester decreases preterm delivery and neonatal morbidity: a systematic review and metaanalysis of individual patient data. Am J Obstet Gynecol. 2012; 206(2): 124.e1-19. doi: 10.1016/j.ajog.2011.12.003.

41. Grobman WA, Thom EA, Spong CY, et al. 17 alphahydroxyprogesterone caproate to prevent prematurity in nulliparas with cervical length less than $30 \mathrm{~mm}$. Am J Obstet Gynecol. 2012; 207(5): 390.e1-8. doi: 10.1016/j.ajog.2012.09.013.

42. Fucron AE, Romero $R$, Plazyo $O$, et al. Vaginal progesterone, but not $17 \alpha$-hydroxyprogesterone caproate, has antiinflammatory effects at the murine maternal-fetal interface. Am J Obstet Gynecol. 2015; 213(6): 846.e1-846.e19. doi: 10.1016/j.ajog.2015.08.010.

43. Carmichael SL, Shaw GM, Laurent C, et al. Maternal progestin intake and risk of hypospadias. Arch Pediatr Adolesc Med. 2005; 159: 957-62. doi: 10.1001/archpedi.159.10.957. 
Iraqi JMS 2018; Vol. 16(2)

44. Dodd JM, Flenady V, Cincotta R, et al. Prenatal administration of progesterone for preventing preterm birth. Cochrane Database Syst Rev. 2013; (7): CD004947. doi: 10.1002/14651858.
E-mail: enas.adnan@yahoo.com enas.adnan@colmed-alnahrain.edu.iq Received May 31 2017

Accepted Oct. $22^{\text {nd }} 2017$ 